\title{
Novel ruthenium(II) cyclopentadienyl thiosemicarbazone compounds with antiproliferative activity on pathogenic trypanosomatid parasites
}

Mariana Fernández, ${ }^{\mathrm{a}+}$ Esteban Rodríguez Arce, ${ }^{\mathrm{a}+}$ Cynthia Sarniguet, ${ }^{\mathrm{a}}$ Tânia S. Morais, ${ }^{\mathrm{b}}$ Ana Isabel Tomaz, ${ }^{b}$ Claudio Olea Azar, ${ }^{c}$ Roberto Figueroa,${ }^{c}$ J. Diego Maya, ${ }^{\mathrm{d}}$ Andrea Medeiros, ${ }^{\mathrm{e}, \mathrm{f}}$ Marcelo Comini, ${ }^{\mathrm{e}}$ M. Helena Garcia, ${ }^{\mathrm{b}}$ Lucía Otero, ${ }^{\mathrm{a}^{*}}$ Dinorah Gambino ${ }^{\mathrm{a}^{*}}$

${ }^{a}$ Cátedra de Química Inorgánica, Facultad de Química, UdelaR, Montevideo, Uruguay

${ }^{\mathrm{b}}$ Centro de Química Estrutural, Faculdade de Ciências da Universidade de Lisboa,

$$
\text { Portugal }
$$

${ }^{\mathrm{c}}$ Departamento de Química Inorgánica y Analítica, Facultad de Ciencias Químicas y Farmacéuticas, Universidad de Chile, Santiago, Chile

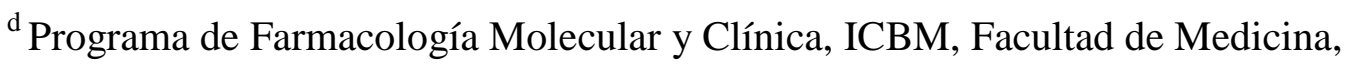
Universidad de Chile, Santiago, Chile

${ }^{\mathrm{e}}$ Institut Pasteur de Montevideo, Group Redox Biology of Trypanosomes, Montevideo,

\section{Uruguay}

${ }_{\mathrm{f}}^{\mathrm{f}}$ Departamento de Bioquímica, Facultad de Medicina, Universidad de la República, Montevideo, Uruguay

\footnotetext{
${ }^{+}$both have equally contributed

*Corresponding authors: Tel +598-29249739; fax +598-29241906

e-mail address: dgambino@fq.edu.uy; luotero@fq.edu.uy
}

Keywords: ruthenium cyclopentadienyl compounds; thiosemicarbazones; Trypanosoma cruzi; Trypanosoma brucei 


\section{Abstract}

Searching for new prospective antitrypanosomal agents, three novel $\mathrm{Ru}(\mathrm{II})-$ cyclopentadienyl compounds, $\left[\mathrm{Ru}\left(\eta^{5}-\mathrm{C}_{5} \mathrm{H}_{5}\right)\left(\mathrm{PPh}_{3}\right) \mathrm{L}\right]$, with $\mathrm{HL}=$ bioactive 5-nitrofuryl containing thiosemicarbazones were synthesized and characterized in the solid state and in solution. The compounds were evaluated in vitro on the blood circulating trypomastigote form of Trypanosoma cruzi (Dm28c strain), the infective form of $T$. brucei brucei (strain 427) and on J774 murine macrophages and human-derived EA.hy926 endothelial cells. The compounds were active against both parasites with $\mathrm{IC}_{50}$ values in the micromolar range. Interestingly, they are much more active on $T$. cruzi than previously developed $\mathrm{Ru}(\mathrm{II})$ classical and organometallic compounds with the same bioactive ligands. The new compounds showed moderate to very good selectivity towards the parasites in respect to mammalian cells. The global results point at $\left[\mathrm{RuCp}\left(\mathrm{PPh}_{3}\right) \mathrm{L} 2\right](\mathrm{L} 2=N$-methyl derivative of 5-nitrofuryl containing thiosemicarbazone and $\mathrm{Cp}=$ cyclopentadienyl) as the most promising compound for further developments $\left(\mathrm{IC}_{50} T\right.$. cruzi $=0.41 \mu \mathrm{M} ; \mathrm{IC}_{50}$ T. brucei brucei $\left.=3.5 \mu \mathrm{M}\right)$. Moreover, this compound shows excellent selectivity towards T. cruzi (SI >49) and good selectivity towards T. brucei brucei (SI >6). In order to get insight into the mechanism of antiparasitic action, the intracellular free radical production capacity of the new compounds was assessed by ESR. DMPO (5,5-dimethyl-1-pirroline- $N$-oxide) spin adducts related to the bioreduction of the complexes and to redox cycling processes were characterized. In addition, DNA competitive binding studies with ethidium bromide by fluorescence measurements showed that the compounds interact with this biomolecule. 


\section{Introduction}

Neglected tropical diseases are a diverse group of 17 diseases caused by pathogenic bacteria, helminth, protozoa or virus that thrive mainly among the poorest world populations [1,2]. Among them, American Trypanosomiasis (Chagas disease) and Human African Trypanosomiasis (HAT, sleeping sickness), caused by the genetically related trypanosomatid protozoa Trypanosoma cruzi and Trypanosoma brucei (Trypanosoma brucei gambiense and Trypanosoma brucei rhodesiense), respectively, constitute major health concerns in the developing world [2-6]. Moreover, these diseases are currently not geographically confined to endemic areas [7]. In particular, because of the globalization and the migration of unknowingly chronic-phase infected people from Latin America to the rest of the world, Chagas disease has spread becoming a worldwide threat that affects United States, Canada, Australia and some European and Asian countries [3].

Current available treatments of both diseases are decades old and suffer from limited efficacy, undesirable collateral effects and development of resistance. Despite the advances in understanding the biology of both parasites that led to the identification of several potential biochemical targets, no new drugs have entered the clinical practice [8]. Research on new prospective drugs against HAT has only led in recent years to the delivery of a relatively safe nifurtimox-eflornithine combination therapy, the development of pentamidine-like prodrugs and the entry into clinical trials of two oral drug candidates, fexinidazole and an oxaborole [9]. Certain antifungal triazoles and protease inhibitors have shown potential in experimental models of infection with $T$. cruzi $[10]$. Nevertheless, the promising sterol biosynthesis inhibitor posaconazole, that 
entered clinical trials in recent years, did not show the expected results in chagasic patients [11].

Therefore, novel strategies for drug design are urgently needed for both diseases. The decoded genomas of $T$. cruzi and T. brucei show a high degree of similarity [12]. Based on the recognition of common targets in both trypanosomatid parasites, compounds that could affect these targets being effective against both protozoa could offer an innovative approach for anti-trypanosomatid drug discovery $[3,4]$.

The development of bioactive metal-based compounds has been recognized as a promising approach in the search for more effective and less toxic antiparasitic drugs [13-20]. In this context, our group has been working during the last years in the design of antiparasitic metal compounds by including in a single chemical entity ligands bearing antitrypanosomal activity and pharmacologically active metals. This strategy, based in the paradigm of the metal-ligand synergism, could provide drugs capable of modulating multiple targets simultaneously. Among the selected bioactive ligands a family of thiosemicarbazones containing the 5-nitrofuryl pharmacophore has been extensively studied by us [13]. We have rationally designed and developed more than sixty compounds of these ligands including palladium, platinum and ruthenium classical complexes as well as ruthenium $\eta^{6}$-arene organometallic compounds and the effect of metal complexation and the presence of different co-ligands on the pharmacological profile of these bioactive ligands was evaluated [21-33].

Among the selected metal centers, ruthenium shows chemical and biological properties that make its compounds particularly suitable for the development of drug candidates. Both biologically relevant oxidation states (II and III) show ligand exchange kinetics similar to $\mathrm{Pt}(\mathrm{II})$ and high coordination versatility, having coordination preferences for sulfur and nitrogen donors which are ubiquitous in the major biomolecules. Moreover, 
the accessibility of the redox potential $\mathrm{Ru}(\mathrm{III}) / \mathrm{Ru}(\mathrm{II})$ in the biological redox potential window could be exploited to improve the effectiveness of ruthenium-based drugs. In addition, ruthenium compounds usually show low toxicity in humans, probably due to metabolic similarities with iron. By mimicking iron metabolism the trafficking of ruthenium compounds into cancer cells but also into trypanosomatid parasites could be favored $[28,34]$.

Ruthenium compounds are the most widely studied non-platinum metal-based drug candidates [35-38] and many of them have been recognized as prospective agents against trypanosomatid parasites $[20,28,39,40]$. The piano stool structured family of $\{$ RuCp $\}$ (ruthenium- $\eta^{5}$-cyclopentadienyl) complexes has been studied against several cancer cell lines revealing very promising agents for cancer therapy [41-45].

Nevertheless, there are not reported studies so far concerning the potentialities of $\{\mathrm{RuCp}\}$ derived compounds for drug design against trypanosomatids.

Based on these previous results, in this work we have developed a new short series of ruthenium complexes with the 5-nitrofuryl containing thiosemicarbazones HL1-HL3 (Figure 1) as bioactive ligands. Three novel $\mathrm{Ru}(\mathrm{II})-\mathrm{Cp}$ compounds, $\left[\mathrm{Ru}\left(\eta^{5}-\right.\right.$ $\left.\left.\mathrm{C}_{5} \mathrm{H}_{5}\right)\left(\mathrm{PPh}_{3}\right) \mathrm{L}\right]$ were synthesized and characterized in solid state and in solution. The compounds were evaluated in vitro on the blood circulating trypomastigote form of $T$. cruzi (Dm28c strain) and the infective form of T. brucei brucei. The selectivity towards the parasites was assessed by including cytotoxicity studies on J774 murine macrophages and humam-derived EA.hy926 endothelial cells as mammalian cell models. Lipophilicity of the compounds was evaluated searching for correlations with the biological activity. In order to get insight into the potential "dual" mechanism of antiparasitic action, emerging from the coexistence of $\{\mathrm{RuCp}\}$ moiety and the bioactive thiosemicarbazone in the same molecule, the intraparasite production of toxic free 
radicals (main mode of action of the ligands [46]) and the interaction with DNA (one of the reported targets of ruthenium bioactive compounds) [47] were studied.

\section{Figure 1}

\section{Materials and methods}

\subsection{Materials}

All common laboratory chemicals were purchased from commercial sources and used without further purification. All syntheses were carried out under dinitrogen atmosphere using current Schlenk techniques, and the solvents used were dried by standard methods [48]. The precursor $\left[\mathrm{Ru}\left(\eta^{5}-\mathrm{C}_{5} \mathrm{H}_{5}\right)\left(\mathrm{PPh}_{3}\right)_{2} \mathrm{Cl}\right]$ was synthesized from $\mathrm{RuCl}_{3}$, triphenylphosphane $\left(\mathrm{PPh}_{3}\right)$ and freshly distilled cyclopentadiene in ethanol according to a previously reported procedure [49]. Thiosemicarbazone ligands HL1-HL3 (Fig. 1) were prepared according to previously published procedures [46].

\subsection{Synthesis of $\left[R u C p\left(P P h_{3}\right) L\right]$}

$\left[\mathrm{RuCp}\left(\mathrm{PPh}_{3}\right)_{2} \mathrm{Cl}\right](0.5 \mathrm{mmol}, 0.320 \mathrm{~g})$ was dissolved in dried distilled dichloromethane. The solid thiosemicarbazone ligand (0.5 mmol; $0.113 \mathrm{~g} \mathrm{HL1,} 0.120 \mathrm{~g}$ HL2, $0.145 \mathrm{~g}$ HL3) and $6 \mathrm{~mL}$ dried methanol were added to the solution and the mixture was allowed to react at reflux temperature for $24 \mathrm{~h}$. The solvent was evaporated in vacuo. The obtained solid was purified by separation through a silica column under $\mathrm{N}_{2}$ using dried distilled dichloromethane as the mobile phase. The eluate was evaporated to dryness in vacuo and the obtained blue-violet solid was recrystallized from a mixture dichloromethane-hexane (1:2) in refrigerator. 
[RuCp(PPh $)_{3}$ L1], 1. Yield: $60 \mathrm{mg}, 18 \%$. Blue-violet solid. Anal. calc. for $\mathrm{C}_{30} \mathrm{H}_{27} \mathrm{~N}_{4} \mathrm{O}_{3}$ PRuS: C, 54.95; H, 4.15; N, 8.54; S, 4.89. Found: C, 55.00; H, 4.13; N, 8.60; S, 4.91. $\Lambda_{\mathrm{M}}$ (DMSO): $3.0 \mathrm{Scm}^{2} \mathrm{~mol}^{-1} . \lambda_{\max }(\mathrm{DMSO}) 573 \mathrm{~nm}\left(\varepsilon=6.6 \times 10^{3} \mathrm{M}^{-1} \mathrm{~cm}^{-}\right.$ $\left.{ }^{1}\right), 415 \mathrm{~nm}\left(\varepsilon=5.4 \times 10^{3} \mathrm{M}^{-1} \mathrm{~cm}^{-1}\right)$. FTIR $\left(\mathrm{KBr}, \mathrm{cm}^{-1}\right): 3051, \mathrm{Cp} ; 1578, v(\mathrm{C}=\mathrm{N}), 1348$, $v_{\mathrm{s}}\left(\mathrm{NO}_{2}\right) ; 1138, v(\mathrm{~N}-\mathrm{N}) ; 806, \delta\left(\mathrm{NO}_{2}\right)+$ furan. ${ }^{1} \mathrm{H} \mathrm{NMR}\left[\left(\mathrm{CD}_{3}\right)_{2} \mathrm{CO}, \mathrm{Me}_{4} \mathrm{Si}, \delta / \mathrm{ppm}\right]: 8.42$ $[\mathrm{s}, 1, \mathrm{H} 5], 7.45\left[\mathrm{~d}, J_{\mathrm{H}, \mathrm{H}}=3.8 \mathrm{~Hz}, 1, \mathrm{H} 3\right], 7.39-7.29\left[\mathrm{~m}, 16, \mathrm{H} 9+\mathrm{PPh}_{3}\right], 7.22\left[\mathrm{~d}, J_{\mathrm{H}, \mathrm{H}}=\right.$ $3.8 \mathrm{~Hz}, 1, \mathrm{H} 2], 4.51\left[\mathrm{~s}, 5, \mathrm{C}_{5} \mathrm{H}_{5}\right], 2.76$ [s, 3, H10]. ${ }^{13} \mathrm{C}$ NMR $\left[\left(\mathrm{CD}_{3}\right)_{2} \mathrm{CO}, \delta / \mathrm{ppm}\right]: 150.27$ (C1), $150.25(\mathrm{C} 4), 136.66(\mathrm{C} 5), 134.61\left(\mathrm{CH}, \mathrm{PPh}_{3}\right), 132.67\left(\mathrm{CH}, \mathrm{PPh}_{3}\right), 129.52(\mathrm{Cq}$, $\left.\mathrm{PPh}_{3}\right), 128.45\left(\mathrm{CH}, \mathrm{PPh}_{3}\right), 117.81(\mathrm{C} 2), 115.68(\mathrm{C} 3), 79.43\left(\mathrm{C}_{5} \mathrm{H}_{5}\right), 32.65(\mathrm{C} 10) .{ }^{31} \mathrm{P}$ $\operatorname{NMR}\left[\left(\mathrm{CD}_{3}\right)_{2} \mathrm{CO}, \delta / \mathrm{ppm}\right]: 52.10\left[\mathrm{~s}, \mathrm{PPh}_{3}\right]$.

[RuCp(PPh $)_{3}$ L2], 2. Yield: $84 \mathrm{mg}, 25 \%$. Blue-violet solid. Anal. calc. for $\mathrm{C}_{31} \mathrm{H}_{29} \mathrm{~N}_{4} \mathrm{O}_{3}$ PRuS: C, 55.60; H, 4.36; N, 8.37; S, 4.79. Found: C, 55.64; H, 4.34; N, 8.35; S, 4.77. $\Lambda_{\mathrm{M}}(\mathrm{DMSO}): 2.0 \mathrm{Scm}^{2} \mathrm{~mol}^{-1} . \lambda_{\max }(\mathrm{DMSO}) 567 \mathrm{~nm}\left(\varepsilon=6.5 \times 10^{3} \mathrm{M}^{-1} \mathrm{~cm}^{-}\right.$ $\left.{ }^{1}\right), 415 \mathrm{~nm}\left(\varepsilon=6.8 \times 10^{3} \mathrm{M}^{-1} \mathrm{~cm}^{-1}\right)$. FTIR $\left(\mathrm{KBr}, \mathrm{cm}^{-1}\right): 3054, \mathrm{Cp} ; 1577, v(\mathrm{C}=\mathrm{N}), 1350$, $v_{\mathrm{S}}\left(\mathrm{NO}_{2}\right) ; 1147, v(\mathrm{~N}-\mathrm{N}) ; 804, \delta\left(\mathrm{NO}_{2}\right)+$ furan. ${ }^{1} \mathrm{H} \mathrm{NMR}\left[\left(\mathrm{CD}_{3}\right)_{2} \mathrm{CO}, \mathrm{Me}_{4} \mathrm{Si}, \delta / \mathrm{ppm}\right]:$ 8.41[s, 1, H5], $7.45\left[\mathrm{~d}, J_{\mathrm{H}, \mathrm{H}}=3.8 \mathrm{~Hz}, 1, \mathrm{H} 3\right], 7.38-7.31\left[\mathrm{~m}, 16, \mathrm{H} 9+\mathrm{PPh}_{3}\right], 7.23\left[\mathrm{~d}, J_{\mathrm{H}, \mathrm{H}}\right.$ $=3.8 \mathrm{~Hz}, 1, \mathrm{H} 2], 4.50\left[\mathrm{~s}, 5, \mathrm{C}_{5} \mathrm{H}_{5}\right.$ ], 3.30 [quint, $\left.J_{\mathrm{H}, \mathrm{H}}=7.2 \mathrm{~Hz}, 2, \mathrm{H} 10\right], 1.15\left[\mathrm{t}, J_{\mathrm{H}, \mathrm{H}}=7.2\right.$ $\mathrm{Hz}, 3, \mathrm{H} 11] .{ }^{13} \mathrm{C} \mathrm{NMR}\left[\left(\mathrm{CD}_{3}\right)_{2} \mathrm{CO}, \delta / \mathrm{ppm}\right]: 151.44(\mathrm{C} 4), 149.83(\mathrm{C} 1), 136.74(\mathrm{C} 5)$, $134.58\left(\mathrm{CH}, \mathrm{PPh}_{3}\right), 133.72\left(\mathrm{Cq}, \mathrm{PPh}_{3}\right), 130.02\left(\mathrm{CH}, \mathrm{PPh}_{3}\right), 128.53\left(\mathrm{CH}, \mathrm{PPh}_{3}\right), 117.30$ (C2), $115.65(\mathrm{C} 3), 79.47\left(\mathrm{C}_{5} \mathrm{H}_{5}\right), 40.91(\mathrm{C} 10), 15.53(\mathrm{C} 11) .{ }^{31} \mathrm{P}$ NMR $\left[\left(\mathrm{CD}_{3}\right)_{2} \mathrm{CO}\right.$, $\delta / \mathrm{ppm}]: 52.27\left[\mathrm{~s}, \mathrm{PPh}_{3}\right]$

[RuCp(PPh$) L 3], 3$. Yield: $65 \mathrm{mg}, 18 \%$. Blue-violet solid. Anal. calc. for $\mathrm{C}_{35} \mathrm{H}_{29} \mathrm{~N}_{4} \mathrm{O}_{3}$ PRuS: C, 58.57; H, 4.07; N, 7.81; S, 4.47. Found: C, 58.45; H, 4.05; N, 
7.85; S, 4.45. $\Lambda_{\mathrm{M}}(\mathrm{DMSO}): 3.0 \mathrm{Scm}^{2} \mathrm{~mol}^{-1} . \lambda_{\max }(\mathrm{DMSO}) 559 \mathrm{~nm}(\mathrm{sh}),\left(\varepsilon=3.9 \times 10^{3} \mathrm{M}^{-}\right.$ $\left.{ }^{1} \mathrm{~cm}^{-1}\right), 421 \mathrm{~nm}\left(\varepsilon=4.9 \times 10^{3} \mathrm{M}^{-1} \mathrm{~cm}^{-1}\right)$. FTIR $\left(\mathrm{KBr}, \mathrm{cm}^{-1}\right): 3057, \mathrm{Cp} ; 1591, v(\mathrm{C}=\mathrm{N})$ $1350, v_{\mathrm{s}}\left(\mathrm{NO}_{2}\right) ; 1153, v(\mathrm{~N}-\mathrm{N}) ; 804, \delta\left(\mathrm{NO}_{2}\right)+$ furan. ${ }^{1} \mathrm{H} \mathrm{NMR}\left[\left(\mathrm{CD}_{3}\right)_{2} \mathrm{CO}, \mathrm{Me}_{4} \mathrm{Si}\right.$, $\delta / \mathrm{ppm}]: 8.72$ [s, 1, H9], 8.54 [s, 1, H5], 7.49 [d, $\left.J_{\mathrm{H}, \mathrm{H}}=7,7 \mathrm{~Hz}, 2, \mathrm{H} 11+\mathrm{H} 15\right], 7.42-7.23$ $\left[\mathrm{m}, 20, \mathrm{H} 2+\mathrm{H} 3+\mathrm{H} 9+\mathrm{H} 12+\mathrm{H} 14+\mathrm{PPh}_{3}\right], 7.00\left[\mathrm{t}, J_{\mathrm{H}, \mathrm{H}}=7,4 \mathrm{~Hz}, 1, \mathrm{H} 13\right], 4.57[\mathrm{~s}, 5$, $\left.\mathrm{C}_{5} \mathrm{H}_{5}\right] .{ }^{13} \mathrm{C}$ NMR $\left[\left(\mathrm{CD}_{3}\right)_{2} \mathrm{CO}, \delta / \mathrm{ppm}\right]: 185.27$ (C8), 151.07 (C4), 140.19 (C5), 136.66 (C10), $134.50\left(\mathrm{CH}, \mathrm{PPh}_{3}\right), 132.69\left(\mathrm{CH}, \mathrm{PPh}_{3}\right), 130.15\left(\mathrm{Cq}, \mathrm{PPh}_{3}\right), 129.36(\mathrm{C} 12+14)$, $128.60\left(\mathrm{CH}, \mathrm{PPh}_{3}\right), 123.55(\mathrm{C} 13), 121.57(\mathrm{C} 11+15), 79.72\left(\mathrm{C}_{5} \mathrm{H}_{5}\right) .{ }^{31} \mathrm{P} \mathrm{NMR}$ $\left[\left(\mathrm{CD}_{3}\right)_{2} \mathrm{CO}, \delta / \mathrm{ppm}\right]: 51.97\left[\mathrm{~s}, \mathrm{PPh}_{3}\right]$

\subsection{Physicochemical characterization}

C, H and N analyses were carried out with a Thermo Scientific Flash 2000 elemental analyzer. Conductimetric measurements were done over time (5 days) at $25^{\circ} \mathrm{C}$ in $10^{-3}$ M DMSO solutions using a Conductivity Meter 4310 Jenway to determine the type of electrolyte and to assess the stability of the complex in such medium [50]. UV-visible (UV-vis) spectra were measured in DMSO in the range $300-800 \mathrm{~nm}$ with a spectrophotometer Shimadzu UV 1603 instrument. The spectra of $0.1 \mathrm{mM}$ solutions were measured with time as an additional method to evaluate the stability of the complexes. The FTIR absorption spectra $\left(4000-300 \mathrm{~cm}^{-1}\right)$ were measured as $\mathrm{KBr}$ pellets with a Shimadzu IRPrestige-21 instrument. ${ }^{1} \mathrm{H},{ }^{13} \mathrm{C}$ and ${ }^{31} \mathrm{P}$ NMR spectra were recorded on a Bruker Avance 400 spectrometer at probe temperature. The ${ }^{1} \mathrm{H}$ and ${ }^{13} \mathrm{C}$ chemical shift $\left(\mathrm{s}=\right.$ singlet; $\mathrm{d}=$ duplet; $\mathrm{t}=$ triplet; $\mathrm{m}=$ multiplet for $\left.{ }^{1} \mathrm{H}\right)$ are reported in parts per million (ppm) downfield from internal $\mathrm{Me}_{4} \mathrm{Si}$ and the ${ }^{31} \mathrm{P}$ NMR spectra are reported in ppm downfield from external standard $85 \% \mathrm{H}_{3} \mathrm{PO}_{4}$.

Electrochemical behaviour was studied by cyclic voltammetry recorded in an Epsilon 
Electrochemical Analyzer. Reduction was studied employing a hanging drop mercury electrode (HDME) as working electrode, a platinum wire was used as counter electrode, while a $\mathrm{Ag} / \mathrm{Ag}+$ electrode was used as a reference electrode. Oxidation was studied using a standard electrochemical three-electrode cell consisting of a carbon disk working electrode, a platinum wire auxiliary electrode and a $\mathrm{Ag} / \mathrm{AgCl}$ reference electrode. Measurements were performed at room temperature in 1mM DMSO solutions of the complexes using tetrabutyl amonium hexafluorophosphate (c.a. $0.1 \mathrm{M}$ ) as supporting electrolyte. Solutions were deoxygenated via purging with nitrogen for 15 min prior to the measurements. A continuous gas stream was passed over the solution during the measurements.

\subsection{Biological studies}

2.4.1. Viability on $T$. cruzi (Dm28c clone) trypomastigotes. Vero cells were infected with $T$. cruzi metacyclic trypomastigotes from 15 days old Dm28c clone epimastigote cultures. Subsequently, the trypomastigotes harvested from this culture were used to infect further Vero cell cultures at a multiplicity of infection (MOI) of 10. These trypomastigote-infected Vero cell cultures were incubated at $37{ }^{\circ} \mathrm{C}$ in humidified air and $5 \% \mathrm{CO}_{2}$ for 5 to 7 days. After this time, culture media were collected and centrifuged at 3,000 $\mathrm{x} g$ for $5 \mathrm{~min}$. The trypomastigote-containing pellets were resuspended in RPMI media supplemented with 5\% fetal bovine serum and penicillinstreptomycin at a final density of $1 \times 10^{7}$ parasites/mL. $2.10 \times 10^{8}$ trypomastigotes are equivalent to $1 \mathrm{mg}$ of protein or $12 \mathrm{mg}$ of wet weight. Viability assays were performed by using the MTT (3-(4,5-dimethylthiazol-2-yl)-2,5-diphenyl tetrazolium bromide) reduction method as previously described [51,52]. Briefly, 1 x $10^{7}$ trypomastigotes were incubated in fetal bovine serum-RPMI culture medium at $37^{\circ} \mathrm{C}$ for $24 \mathrm{~h}$ with and 
without the complexes under study at different concentrations. An aliquot of the parasite suspension was extracted and it was incubated in a flat-bottom 96-well plate and MTT was added at a final concentration of $0.5 \mathrm{mg} / \mathrm{mL}$, incubated at $28{ }^{\circ} \mathrm{C}$ for $4 \mathrm{~h}$, and then solubilized with $10 \%$ sodium dodecyl sulfate $0.1 \mathrm{mM} \mathrm{HCl}$ and incubated overnight. Formazan formation was measured at $570 \mathrm{~nm}$ with the reference wavelength at $690 \mathrm{~nm}$ in a multiwell reader (Biochrom® Asys Expert Plus, Biochrom, USA). Untreated parasites were used as negative controls (100\% of viability). Finally, a non-linear regression analysis, using Log concentration vs normalized response fit, by Graph Pad prism® software was performed.

\subsubsection{Activity on bloodstream T. brucei brucei strain 427}

The infective form of $T$. brucei brucei strain 427, cell line 449 (encoding one copy of the tet-represor protein: $\operatorname{Pleo}^{\mathrm{R}}$;[53]), was aerobically cultivated in a humidified incubator at $37^{\circ} \mathrm{C}$ with $5 \% \mathrm{CO}_{2}$ in HMI-9 medium [54] supplemented with $10 \%$ (v/v) fetal calf serum (FCS), $10 \mathrm{U} / \mathrm{mL}$ penicillin, $10 \mu \mathrm{g} / \mathrm{mL}$ streptomycin and $0.2 \mu \mathrm{g} / \mathrm{mL}$ phleomycin. The assay was performed as previously described [55]. Ten $\mathrm{mM}$ stock solutions of the compounds were prepared using DMSO as solvent and then diluted in culture medium to obtain seven experimental concentrations (from 25 to $0.3 \mu \mathrm{M}$ ). Compounds, DMSO (up to $1 \%$ ) or medium were immediately added at the concentrations described above and the culture plate was incubated at $37{ }^{\circ} \mathrm{C}$ with $5 \%$ $\mathrm{CO}_{2}$. After $24 \mathrm{~h}$, living parasites were counted with a Neubauer chamber under the light microscope. Each condition was tested in triplicate.

For each compound concentration, cytotoxicity was calculated according to the following equation: Cytotoxicity $(\%)=($ experimental value $-\mathrm{DMSO}$ control $) /($ growth control - DMSO control $) \times 100$. The data were plotted as percentage cytotoxicity versus 
complex concentration. $\mathrm{IC}_{50}$ values were obtained from dose response curves fitted to a sigmoidal equation (Boltzmann model) or extrapolated from non-linear fitting plots.

\subsubsection{Cytotoxicity on murine macrophages}

The $\mathrm{J} 774$ mouse macrophage cell line was cultivated in a humidified $5 \% \mathrm{CO}_{2} / 95 \%$ air atmosphere at $37^{\circ} \mathrm{C}$ in DMEM medium supplemented with $10 \%$ (v/v) FCS, $10 \mathrm{U} / \mathrm{mL}$ penicillin and $10 \mu \mathrm{g} / \mathrm{mL}$ streptomycin. Stock solutions of the compounds to be tested were prepared as described for anti-T. brucei activity tests and diluted in culture medium to obtain seven experimental concentrations (from 100 to $0.5 \mu \mathrm{M}$ ). Each condition was tested in triplicate. The cytotoxic effect of the compounds towards macrophages was evaluated after $24 \mathrm{~h}$ incubation by colorimetric assay with a tetrazolium salt (WST-1 reagent). The absorbance of the formazan dye produced by metabolically active cells was measured at $450 \mathrm{~nm}$ (reference wavelength at $630 \mathrm{~nm}$ ) with an EL 800 microplate reader (Biotek). The methodological procedure is essentially as described previously [32]. Cytotoxicity was calculated and $\mathrm{IC}_{50}$ values were obtained as described for cytotoxicity on T. brucei brucei.

\subsubsection{Cytotoxicity on endothelial mammalian cells}

The endothelial cell lines EA.hy926 (permanent human cell line derived by fusing human umbilical vein endothelial cells-HUVEC with human lung cells-A549) were maintained in the nutrient medium, Iscove's modified Dulbecco's medium (IMDM) (Sigma-Aldrich), was supplemented with $10 \%$ fetal bovine serum, $(25 \mathrm{mM})$, penicillin (100 units $/ \mathrm{ml})$, and streptomycin $(100 \mathrm{mg} / \mathrm{ml})$. Cells were maintained as a monolayer culture in tissue culture flasks (Thermo Scientific Nunc ${ }^{\mathrm{TM}}$ ) in an incubator at $37^{\circ} \mathrm{C}$ in a humidified atmosphere composed of $5 \% \mathrm{CO}_{2}$. Viability assays were performed by using 
the MTT reduction method as previously described for T. cruzi trypomastigote assay (see above).

\subsection{Lipophilicity studies}

Reversed-phase TLC experiments were done on precoated TLC plates SIL RP18W/UV 254 and eluted with DMSO:physiological serum (60:40, v/v). Stock solutions were prepared in pure methanol (Aldrich) prior to use. The plates were developed in a closed chromatographic tank, dried and the spots were detected under UV light. The $\mathrm{R}_{\mathrm{f}}$ values were averaged from two to three determinations, and converted to $R_{M}$ via the relationship: $\mathrm{R}_{\mathrm{M}}=\log _{10}\left[\left(1 / \mathrm{R}_{\mathrm{f}}\right)-1\right][56-58]$.

\subsection{Insight into the mechanism of action}

\subsubsection{Generation of free radical species in $T$. cruzi}

The free radical production capacity of the new complexes was assessed in the parasite with ESR (electron spin resonance) using DMPO (5,5-dimethyl-1-pirroline- $N$-oxide) for spin trapping. Each tested compound was dissolved in DMSO (spectroscopy grade, approx. $1 \mathrm{mM}$ ) and the solution was added to a mixture containing the epimastigote form of $T$. cruzi (Dm28c strain; final protein concentration, $4-8 \mathrm{mg} / \mathrm{mL}$ ) and DMPO (final concentration, $250 \mathrm{mM}$ ). The mixture was transferred to a $50-\mu \mathrm{L}$ capillary. ESR spectra were recorded in the X band $(9.85 \mathrm{GHz})$ using a Bruker ECS 106 spectrometer with a rectangular cavity and 50-kHz field modulation. All the spectra were registered in the same scale, after 15 scans $[29,49]$. The ESR spectra were simulated using the program WINEPR Simfonia 1.25 version.

\subsubsection{DNA interaction by fluorescence studies}


Experiments for competitive binding to calf thymus DNA (ctDNA, SIGMA, Type I, No. D-1501) with ethidium bromide (EB, SIGMA) were carried out in $10 \mathrm{mM}$ Tris-HCl buffer at $\mathrm{pH}$ 7.4. Millipore ${ }^{\circledR}$ water was used for the preparation of all aqueous solutions. Fluorescence measurements were carried out on individually prepared samples to ensure the same pre-incubation time for all samples in each assay. Due to the low solubility of the complexes in aqueous media DMSO was used to prepare concentrated stock solutions followed by appropriate dilution to obtain the targeted concentration and the same content of DMSO (5\% v/v) in the final samples. DNA stock solutions were prepared by hydrating ctDNA in Tris- $\mathrm{HCl}$ buffer $(1 \mathrm{mg} / \mathrm{mL}$, $\sim 2 \mathrm{mM}_{\mathrm{n}} \mathrm{nc}^{-1}$ ) by gently stirring the solution overnight. This solution was kept at $4{ }^{\circ} \mathrm{C}$ (in the fridge) in-between measurements and discarded after 4 days. The concentration of each stock solution was determined by UV spectrophotometry using the molar absorption coefficient $\varepsilon(260 \mathrm{~nm})=6600 \mathrm{M}^{-1} \mathrm{~cm}^{-1} \mathrm{nuc}^{-1}$ [59]. A EB $5 \mathrm{mM}$ solution was prepared in Tris- $\mathrm{HCl}$ buffer. ctDNA was pre-incubated with $\mathrm{EB}$ at $4{ }^{\circ} \mathrm{C}$ for $24 \mathrm{~h}$. Samples were prepared with a total concentration of DNA and of EB of $20 \mu \mathrm{M} \cdot$ nuc $^{-1}$ and $10 \mu \mathrm{M}$, respectively, varying the total complex concentration from $1-110 \mu \mathrm{M}$. They were incubated at $37^{\circ} \mathrm{C}$ for $30 \mathrm{~min}$. Samples with complex alone and samples with complex and EB but no DNA were used as blanks.

Fluorescence spectra were recorded from $520 \mathrm{~nm}$ to $650 \mathrm{~nm}$ at an excitation wavelength of $510 \mathrm{~nm}$ on a Shimadzu RF-5301PC spectrofluorimeter. Fluorescence emission intensity was corrected for the absorption and emission inner filter effect at the maximum emission wavelength $(594 \mathrm{~nm})$ using the UV-vis absorption data recorded for each sample according to the following equation [60].

$I F_{\text {corr }}=I F \times 10^{\left(\frac{A b s_{\lambda_{e x c}}+A b s_{\lambda \text { em }}}{2}\right)}$ 


\section{Results and discussion}

Three $\mathrm{Ru}(\mathrm{II})$-cyclopentadienyl complexes including bioactive 5-nitrofuryl containing thiosemicarbazones as ligands were synthesized with high purity and reasonable yields according to the proposed synthetic scheme shown in Figure 1. The new compounds were characterized in the solid state and in solution using different techniques.

Analytical, conductimetric and FTIR and NMR spectroscopic results are in agreement with the formula $\left[\mathrm{RuCp}\left(\mathrm{PPh}_{3}\right) \mathrm{L}\right]$, where $\mathrm{L}$ is the deprotonated form of $\mathrm{HL}=\mathrm{HL} 1-$ HL3. The compounds are non-conducting in DMSO.

\subsection{IR spectroscopic characterization}

Assignments of the main IR bands (Table S1, supplementary material) were made based on our previous reports on vibrational behavior of $\mathrm{Pd}(\mathrm{II})$ and $\mathrm{Ru}(\mathrm{II})$ complexes with the selected thiosemicarbazones as ligands [32,61].

All complexes showed a similar spectral pattern. When compared to the free thiosemicarbazones, observed modifications are consistent with the coordination of these ligands through the thiocarbonylic sulfur and the azomethynic nitrogen. On one side, the $v(\mathrm{C}=\mathrm{N})$ bands of the thiosemicarbazone free ligands, at approximately 1600 $\mathrm{cm}^{-1}$, shift to lower frequencies. In addition, $v(C=S)$ band at around $820-850 \mathrm{~cm}^{-1}$ in the free ligands, should shift to lower wave numbers upon sulfur coordination. Even though, as it had been previously stated, this band could not be unambiguously assigned for the metal compounds [61], significant changes are observed in this region after coordination. The $v(\mathrm{NH})$ band, at approximately $3120-3150 \mathrm{~cm}^{-1}$, is not observed in the complexes due to deprotonation of the thiosemicarbazone ligands. This fact is in agreement with the proposed molecular formulae, $\left[\mathrm{RuCp}\left(\mathrm{PPh}_{3}\right) \mathrm{L}\right]$. In addition, for the three compounds the vibration band assigned to the $\{\mathrm{RuCp}\}$ moiety around $3050 \mathrm{~cm}^{-1}$ 
was identified [62]. Furthermore, coordinated triphenylphosphane bands at c.a. 1400, 690 and $520 \mathrm{~cm}^{-1}$ could be observed in the complexes spectra.

\subsection{NMR results}

${ }^{1} \mathrm{H},{ }^{13} \mathrm{C}$ and ${ }^{31} \mathrm{P}$ NMR experiments were completed by COSY (COSY = correlation spectroscopy), HMQC (HMQC = heteronuclear multiple-quantum correlation) and HMBC $(\mathrm{HMBC}=$ heteronuclear multiple bond correlation $)$ studies in acetone- $\mathrm{d}_{6}$, for a complete characterization of the compounds (Figures S1 to S18, supplementary material). Figure 1 shows the numbering of the ligands.

The analysis of the ${ }^{1} \mathrm{H}$ NMR shows resonances for the $\eta^{5}$-cyclopentadienyl rings in the characteristic range of other ruthenium(II)-cyclopentadienyl complexes [43-45]. The absence of the $\mathrm{H} 7$ signal is in accordance with the deprotonation of the N,S bidentate ligand upon coordination. In addition, coordination leads to a significant downfield shift in the range $1 \mathrm{ppm}$ of the $\mathrm{H} 9$ of the $\mathrm{NH}$ group. This effect can be explained by an efficient $\pi$ back-donation from $\mathrm{Ru}(\mathrm{II}) \mathrm{d}$ orbitals to $\pi^{*}$ orbitals placed at the coordinated $\mathrm{N}$ atom and also to vacant $\mathrm{d}$ orbitals of $\mathrm{S}$. This income of electronic density at the coordinated ligands is also observed in most of the aliphatic and aromatic protons where a shielding of $\sim 0.4 \mathrm{ppm}$ was observed. Interestingly, in the side of the chain containing the furan ring a conjugation of the double bonds is observed, possibly motivated by the presence of the excellent $\mathrm{NO}_{2}$ acceptor group. This effect might explain the deshielding found for $\mathrm{H} 3$ and $\mathrm{H} 5$ protons ( $0.3 \mathrm{ppm})$. A similar effect was also found upon coordination of $\mathrm{O}, \mathrm{N}$ bopy ligand (bopy $=2$-benzoylpyridine) found in the complex $\left[\mathrm{RuCp}\left(\mathrm{PPh}_{3}\right)\right.$ (bopy)][CF $\left.\mathrm{SO}_{3}\right][44]$. 
Although the interpretation of the ${ }^{13} \mathrm{C}$ NMR spectra was not so easy due to the weakness of the main signals of $\mathrm{C} 8$, they still revealed the same general tendency observed for the protons. ${ }^{31} \mathrm{P}$ NMR spectra of the complexes showed a single sharp signal for the phosphane coligand at $\sim 52 \mathrm{ppm}$, showing a deshielding of $\sim 13 \mathrm{ppm}$ originated by the coordination of the $\mathrm{N}, \mathrm{S}$ ligands, thus corroborating the existence of a significant electronic flow from the Ru center to the bidentate ligand.

\subsection{Cyclic voltammetry results}

The electrochemical characterization of the complexes was performed at room temperature by cyclic voltammetry in DMSO solutions using a carbon disk electrode for the anodic scan and a hanging drop mercury electrode for the cathodic one. Obtained voltammograms (recorded at a scan rate of $100 \mathrm{mV} / \mathrm{s}$ ) are shown in Figure 2. Selected electrochemical data are shown in Table 1. All obtained complexes showed a similar voltammetric response in both cathodic and anodic directions.

On the reverse anodic scan, a reversible redox couple at around $0.4 \mathrm{~V} v s . \mathrm{Ag} / \mathrm{AgCl}$ was observed for the three complexes (Table 1). This electrochemical process was attributed to the $\mathrm{Ru}(\mathrm{II}) / \mathrm{Ru}(\mathrm{III})$ oxidation as previously observed for other $\mathrm{Ru}(\mathrm{II})$ - $\mathrm{Cp}$ complexes [43-45]. The effect of the scan rate on the electrochemical response of this couple was investigated between 50 and $500 \mathrm{mV} / \mathrm{s}$. For all complexes, the anodic and cathodic peak

potentials $\left(E_{p a}\right.$ and $\left.E_{p c}\right)$ were not dependent on the scan rate. In addition, the ipa/ $v^{1 / 2}$ value was invariant with changing scan rates and the ratio of cathodic to anodic peak currents $\left(\mathrm{i}_{\mathrm{pc}} / \mathrm{i}_{\mathrm{pa}}\right)$ remained near to unit (Fig. S19, S20, S21, supplementary material). This behaviour is expected for a reversible charge transfer process [63].

Three ligand centered redox couples were observed when the potential was scanned in the negative direction. As previously reported for the free 5-nitrofuryl containing 
thiosemicarbazone ligands and their metal complexes [21-23,31,32,64] a quasireversible wave (couple II) at $-1.1 \mathrm{~V} v s$. $\mathrm{Ag} / \mathrm{Ag}+$, could be assigned to a process involving a one-electron transfer, which leads to the generation of the anion radical $\mathrm{RNO}_{2}{ }^{--}$by reduction of the nitro moiety. Other ligand centered waves corresponding to further reduction of the nitro moiety (couple III) and a self-protonation process (couple I) were also observed for the three complexes.

It had been previously demonstrated that the first step of the mechanism of antiparasitic action of the 5-nitrofuryl-containing thiosemicarbazones and their metal complexes involves the reduction of the nitro moiety. Through redox cycling, the formed nitro anion radical would generate other radical species toxic for the parasite [46]. In this regard, the reduction potential of the nitro group could be a way of predicting how easy this reduction process in vivo could be. Obtained peak potentials and those of the corresponding thiosemicarbazone ligands are shown in Table 1. The reduction potentials of the nitro moiety diminished in about $0.05 \mathrm{~V}$ because of the formation of the complexes. This positive influence of complexation could conduct to an increased biological activity.

\section{Figure 2}

\section{Table 1}

\subsection{Biological results}

The stability of the obtained compounds in DMSO was studied by conductivity measurements and UV-vis spectroscopy. The three ruthenium(II) cyclopentadienyl complexes were stable for at least $24 \mathrm{~h}$, the experimental time involved in the biological evaluations. 


\subsubsection{In vitro antiparasitic activity}

\subsubsection{Anti-T. cruzi activity}

All the new ruthenium-Cp compounds were active against $T$. cruzi (trypomastigotes Dm28c) with $\mathrm{IC}_{50}$ values in the micromolar range (Table 2). With the exception of $\left[\mathrm{RuCp}\left(\mathrm{PPh}_{3}\right) \mathrm{L} 3\right]$, the compounds showed a 4- to 45 - fold increase of activity in respect to the corresponding thiosemicarbazone ligand. In addition, the two most active compounds, [RuCp$\left.\left(\mathrm{PPh}_{3}\right) \mathrm{L} 1\right]$ and $\left[\mathrm{RuCp}\left(\mathrm{PPh}_{3}\right) \mathrm{L} 2\right]$, are 5 and 49 times more active than the reference trypanocidal drug Nifurtimox $\left(\mathrm{IC}_{50}=20.1 \pm 0.8 \mu \mathrm{M}\right)$, respectively [31].

The new cyclopentadienyl compounds are much more active than previously developed $\mathrm{Ru}(\mathrm{II})$ classical and organometallic compounds: $\left[\mathrm{RuCl}_{2}(\mathrm{HL})(\mathrm{HPTA})_{2}\right] \mathrm{Cl}_{2},\left[\mathrm{Ru}_{2}(\mathrm{p}-\right.$ cymene $\left.)_{2}(\mathrm{~L})_{2}\right] \mathrm{Cl}_{2}$ and $\left[\mathrm{Ru}_{2}(\mathrm{p} \text {-cymene })_{2}(\mathrm{~L})_{2}\right]\left(\mathrm{PF}_{6}\right)_{2}[31,33]$. In fact, and to the best of our knowledge, [RuCp $\left.\left(\mathrm{PPh}_{3}\right) \mathrm{L} 2\right]$ is the most active metal compound including a 5-nitrofuryl derived thiosemicarbazone reported to date.

\section{Table 2}

\subsubsection{Anti - T. brucei activity}

All the new Cp compounds showed activity against infective $T$. brucei brucei showing $\mathrm{IC}_{50}$ values in the micromolar range, and $\left[\mathrm{RuCp}\left(\mathrm{PPh}_{3}\right) \mathrm{L} 2\right]$ and $\left[\mathrm{RuCp}\left(\mathrm{PPh}_{3}\right) \mathrm{L} 3\right]$ resulted more active than the corresponding thiosemicarbazone ligand. Both displayed inhibitory activities of the same order of magnitude than the organometallic compounds $\left[\mathrm{Ru}_{2}(\mathrm{p}-\right.$ cymene $\left.)_{2}(\mathrm{~L})_{2}\right](\mathrm{X})_{2}$, previously developed with the same HL ligands [32]. 


\subsubsection{Cytotoxicity on mammalian cells}

The specificity of the antitrypanosomal activity of the new compounds was evaluated by analyzing their cytotoxicity against a murine macrophage like cell line (J774) and a human-derived endothelial cell line (EA.hy926). Almost all the new compounds showed moderate to very good selectivity towards the parasites when compared to the selected mammalian cell lines (Table 2). Although an exact determination was not possible due to solubility problems in the culture medium, cytotoxicity was in all the cases $>20 \mu \mathrm{M}$.

These data point to $\left[\mathrm{RuCp}\left(\mathrm{PPh}_{3}\right) \mathrm{L} 2\right]$ as the most promising compound for further developments. It shows a submicromolar $\mathrm{IC}_{50}$ value on $T$. $\operatorname{cruzi}\left(\mathrm{IC}_{50}=0.41 \mu \mathrm{M}\right)$ together with a low $\mathrm{IC}_{50}$ value against $T$. brucei brucei $\left(\mathrm{IC}_{50}=3.5 \mu \mathrm{M}\right)$. Moreover, this compound shows excellent selectivity towards T. cruzi (SI >49) and moderate to ggod selectivity towards $T$. brucei brucei $(\mathrm{SI}>6)$. It could be further studied as a prospective broad spectrum antitrypanosomal agent.

Overall, the results confirm the validity of our rational design project that involves the modification of the coordination sphere of $\mathrm{Ru}(\mathrm{II})$ in complexes with bioactive 5nitrofuryl containing thiosemicarbazones as ligands in order to improve their antiparasitic activity.

\subsection{Lipophilicity}

Lipophilicity is among the prime factors controlling transmembrane transport and interaction with biological receptors. Therefore, it is a relevant physicochemical property of prospective drugs that could be correlated with the observed biological 
activity [65]. The effect of complex formation and of the presence of the Cp moiety on lipophilicity was experimentally determined using reversed-phase TLC, where the stationary phase (precoated TLC-C18) may be considered to simulate lipids of biological membranes or receptors, and the mobile phase (DMSO/physiological serum $60: 40 \mathrm{v} / \mathrm{v}$ ) resembles the aqueous biological milieu. The composition of the mobile phase was selected in order to allow differentiating complexes according to their lipophilicity and comparing with the free thiosemicarbazones and other previously developed $\mathrm{Ru}(\mathrm{II})$ compounds with these ligands [30,31].

All the obtained complexes were more lipophilic than the corresponding thiosemicarbazone ligands (Table 3). As expected, the lipophilicity of the complexes increases as the $N$-substituent in the thiosemicarbazone ligand changes from methyl to phenyl, being [RuCp $\left(\mathrm{PPh}_{3}\right) \mathrm{L} 3$ ] the most lipophilic complex. Obtained $\mathrm{R}_{\mathrm{M}}$ values were similar to those previously reported for $\left[\mathrm{Ru}^{\mathrm{II}} \mathrm{Cl}_{2}(\mathrm{HL})_{2}\right]$ and $\left[\mathrm{Ru}^{\mathrm{II}} \mathrm{Cl}_{2}(\mathrm{HL})(\mathrm{HPTA})_{2}\right] \mathrm{Cl}_{2}$ complexes (PTA = 1,3,5-triaza-7-phosphaadamantane) [30,31].

\section{Table 3}

No correlation between lipophilicity and antiparasitic activity could be observed. In fact, among the developed Ru-Cp complexes, the most lipophilic one, [RuCp$\left.\left(\mathrm{PPh}_{3}\right) \mathrm{L} 3\right]$, is the less active. In addition, even though the compounds synthesized in this work were as lipophilic as other ruthenium complexes previously obtained $\left(\left[\mathrm{RuCl}_{2}(\mathrm{HL})(\mathrm{HPTA})_{2}\right] \mathrm{Cl}_{2}\right.$, for example), they are much more active. As could be expected, lipophilicity is only one of the factors that could influence compounds biological activity as well as polar, electronic and steric effects. For this family of compounds, it does not seem to be a relevant factor. 


\subsection{Insight into the mechanism of action}

\subsubsection{Production of free radicals in T. cruzi}

As previously stated, the mechanism of anti T. cruzi action of the selected 5-nitrofuryl derived thiosemicarbazones involves the intraparasite bioreduction leading to toxic free radicals $[26,46]$. This mechanism of action seems to be retained by other previously reported metal complexes of these bioactive ligands [21-23,27,29,31,33]. As previously stated, the first step of this mechanism involves the one electron reduction of the nitro moiety. The cyclic voltammetry studies showed that this reduction could be more easily achieved for the ruthenium componds than for the free thiosemicarbazone ligands.

Therefore, the free radical production capacity of the new ruthenium cyclopentadienyl compounds was assessed by ESR, incubating the compounds with $T$. cruzi (Dm28c strain) epimastigotes. DMPO was added as spin trapping agent to detect free radical species having short half-lives. ESR spectra of all complexes showed a similar line pattern. The global behavior is exemplied by the ESR spectrum of [ $\left.\mathrm{RuCp}\left(\mathrm{PPh}_{3}\right) \mathrm{L} 2\right]$, displayed in Figure 3.

In all cases a thirteen line spectral pattern was observed. These lines correspond to three different DMPO spin adducts. One of these spin adducts (marked with ", Figure 3) corresponds to the trapping of a carbon-centered radical by DMPO showing the characteristic six lines pattern [66]. This trapped species could be related to the bioreduction of the complexes, generating a nitroheterocyclic radical. The second group of signals (*, Figure 3 ), consisting of four lines, corresponds to the DMPO-OH adduct [66]. Intracellular hydroxyl radical species would arise due to redox cycling processes. The third line pattern (\#, Figure 3 ) could be related to the oxidation of the spin trap and/or the rapid decomposition of DMPO-OH adduct [66,67]. 


\section{Figure 3}

Thus, the biological free radical production capacity of the new compounds was confirmed since all of them were capable to produce free radicals in the intact parasite giving an ESR spectrum with the described pattern of signals. It can be concluded that the metal compounds would maintain the mode of action of the 5-nitrofuryl pharmacophore.

\subsubsection{DNA interaction}

EB fluorescent DNA probe was used to access the interaction of the new complexes with DNA. EB is a conjugate planar molecule with weak intrinsic fluorescence emission at the selected excitation wavelength, and in $\mathrm{pH}$ 7.4 Tris buffer/2\%DMSO its spectrum shows an emission maximum at $601 \mathrm{~nm}$. Intercalation of EB into double stranded DNA induces an increase of the fluorescence quantum yield $[68,69]$. In addition, in the spectrum of the $\{$ DNA-EB $\}$ adduct the emission maximum is shifted to $594 \mathrm{~nm}$ in our experimental conditions. At the selected excitation wavelength $\left(\lambda_{\text {exc }}=510 \mathrm{~nm}\right)$, both DNA and the complexes are non-fluorescent in $\mathrm{pH}=7.410 \mathrm{mM}$ TRIS/2\% DMSO, and no fluorescence emission results from their direct interaction with DNA.

Results obtained for the titration of the $\{\mathrm{DNA}-\mathrm{EB}\}$ adduct with the new $\left[\mathrm{RuCp}\left(\mathrm{PPh}_{3}\right) \mathrm{L}\right]$ compounds are summarized in Figure 4. A quenching in the emission of $\{$ DNA-EB $\}$ is observed upon increasing complex concentration, the extent of the quenching being quite similar for the three complexes. These results are consistent with an EB displacement from the $\{$ DNA-EB $\}$ adduct brought upon by the complex binding to 
DNA in an intercalative-like manner or by interaction with DNA by inducing conformational changes which cause the disruption of EB binding sites.

\section{Figure 4}

The mechanisms involved in the fluorescence quenching process for the complexes can be accessed by a Stern-Volmer analysis according to

$$
\frac{I_{F 0}}{I_{F}}=1+K_{S V}[Q]
$$

where $I_{F 0}$ and $I_{\mathrm{F}}$ is the emission fluorescence intensity of the $\{\mathrm{DNA}-\mathrm{EB}\}$ adduct in the absence and in the presence of the complex, $K_{\mathrm{SV}}$ the Stern-Volmer constant, and [Q] the concentration of the quencher (in this case, the complexes) [60]. Equation 1 predicts a linear plot for $I_{\mathrm{F} 0} / I_{\mathrm{F}}$ for a homogeneously emitting system. Stern-Volmer analysis for the $\left[\mathrm{RuCp}\left(\mathrm{PPh}_{3}\right) \mathrm{L}\right]$ complexes showed in each case a positive deviation from the linearity detected as a curve upward. This effect is frequently observed when the extent of quenching is relatively large. In the low complex concentration range the plot $I_{\mathrm{FO}} / I_{\mathrm{F}}$ is linear and the $K_{\mathrm{SV}}$ constant can be calculated for each system (Table 4).

\section{Table 4}

Results show that all complexes tested interact with DNA with similar affinities (Table 4) independently on the nature of L ligand. As expected, obtained Ksv values were lower than those previously reported for other ruthenium complexes with typical planar

DNA intercalating ligands. In particular, $\left[\mathrm{Ru}(\mathrm{bpy})(\mathrm{pp}[2,3] \mathrm{p})_{2}\right]\left(\mathrm{ClO}_{4}\right)_{2}$ and

$\left[\mathrm{Ru}(\mathrm{phen})(\mathrm{pp}[2,3] \mathrm{p})_{2}\right]\left(\mathrm{ClO}_{4}\right)_{2}$ with $\mathrm{pp}[2,3] \mathrm{p}=$ pyrido[2',3':5,6]pyrazino[2,3-

f][1,10]phenanthroline showed $\log K_{\mathrm{SV}}=5.8$ and 6.0 respectively [70]. 
Even though results show that DNA could be a target of these complexes, no correlation between interaction with this biomolecule and the biological activity was observed.

\section{Conclusions}

Three novel Ru(II)-cyclopentadienyl compounds, $\left[\mathrm{Ru}\left(\eta^{5}-\mathrm{C}_{5} \mathrm{H}_{5}\right)\left(\mathrm{PPh}_{3}\right) \mathrm{L}\right]$, with $\mathrm{L}=$ bioactive 5-nitrofuryl containing thiosemicarbazones were synthesized and characterized in the solid state and in solution.

The compounds were active in vitro against the bloodstream forms of Trypanosoma cruzi (Dm28c strain) and T. brucei brucei (strain 427) with $\mathrm{IC}_{50}$ values in the micromolar range. In addition, they were much more active on $T$. cruzi than previously developed $\mathrm{Ru}(\mathrm{II})$ classical and organometallic compounds with the same ligands. Almost all the new compounds showed moderate to very good selectivity towards the parasites in respect to the selected mammalian cell models.

The results confirm the validity of our rational design project that involves the modification of the co-ligands included in the coordination sphere of $\mathrm{Ru}(\mathrm{II})$ complexes with bioactive 5-nitrofuryl containing thiosemicarbazones as ligands in order to improve their antiparasitic activity.

In regard to the probable mechanism of action, the compounds were capable to produce free radicals in the intact parasite. Thus, it can be concluded that these metal compounds would maintain the mode of action of the 5-nitrofuryl pharmacophore. In addition, the complexes demonstrated their ability to interact with DNA showing similar affinities. The global results point at $\left[\mathrm{RuCp}\left(\mathrm{PPh}_{3}\right) \mathrm{L} 2\right]$ as the most promising antitrypanosomal compound for further developments. 


\section{Acknowledgements}

E.R.A. wishes to thank ANII for a postgraduate grant. Authors thank CSIC-UdelaR (project 800), PEDECIBA and ANII-SNI, Uruguay and FONDECYT projects 1150175 and 1130189, Chile. M.A.C. acknowledges the support of FOCEM (MERCOSUR Structural Convergence Fund, COF 03/11). A.I.T. and T.M. thank the Portuguese Foundation for Science and Technology (FCT) for financial support (the IF Initiative IF/01179/2013 and post-doctoral grant SFRH/BPD/93513/2013). Portuguese coauthors also thank FCT for projects PTDC/QUI-QUI/118077/2010 and UID/QUI/00100/2013.

\section{References}

[1] http://www.who.int/neglected_diseases/diseases/en/ accessed on January $10^{\text {th }} 2015$.

[2] P.J. Hotez, D.H. Molyneux, A. Fenwick, J. Kumaresan, S. Ehrlich Sachs, J.D.

Sachs, L. Savioli, Engl. J. Med. 357 (2007) 1018 - 1027.

[3] I. Ribeiro, A.M. Sevcsik, F. Alves, G. Diap, R. Don, M.O. Harhay, S. Chang, B. Pecoul, PLoS Negl. Trop. Dis. 3(7)(2009) e484.

[4] A. Cavalli, M.L. Bolognesi, J. Med. Chem. 52 (2009) 7339 - 7359.

[5] G. Le Loup, G. Pialoux, F.X. Lescure, Curr. Opin. Infect. Dis. 24 (2011) 428 - 434.

[6] A. J. Romanha, S. Lisboa de Castro, M. de Nazaré Correia Soeiro, J. Lannes-Vieira, I. Ribeiro, A. Talvani, B. Bourdin, B. Blum, B. Olivieri, C. Zani, C. Spadafora, E.

Chiari, E. Chatelain, G. Chaves, J. E. Calzada, J. M. Bustamante, L. Freitas-Junior, L. Romero, M. T. Bahia, M. Lotrowska, M. Soares, S. Gumes Andrade, T. Armstrong, W. Degrave, Z. de Araújo Andrade, Mem. Inst. Oswaldo Cruz 105 (2010) 233-238.

[7] European Commission and Rare diseases:

http://ec.europa.eu/health/rare_diseases/policy/index_en.htm accessed on December $10^{\text {th }} 2014$. 
[8] H. Cerecetto, M. González, Pharmaceuticals 3 (2010) 810-838. A. R. Renslo, J. H. McKerrow, Nature Chem. Biol. 2 (2006) 701-710.

[9] D. Horn, M. T. Duraisingh, Annu. Rev. Pharmacol. Toxicol. 54 (2014) 71-94.

[10] K. Stuart, R. Brun, S. Croft, A. Fairlamb, R. E. Gürtler, J. McKerrow, S. Reed, R. Tarleton, J. Clin. Invest. 118 (2008) 1301-1310.

[11] I. Molina, J. Gómez i Prat, F. Salvador, B. Treviño, E. Sulleiro, N. Serre, D. Pou, S. Roure, J. Cabezos, L. Valerio, A. Blanco-Grau, A. Sánchez-Montalvá, X. Vidal, A. Pahissa, N Engl J Med 370 (2014)1899-1908.

[12] El-Sayed NM et al Science 309 (2005) 404-409.

[13] M. Navarro, G. Gabbiani, L. Messori, D. Gambino, Drug Discov. Today 15 (2010) $1070-1078$.

[14] D. Gambino, Coord. Chem. Rev. 255 (2011) 2193 - 2203.

[15] J. Costa Pessoa, S. Etcheverry, D. Gambino, Coord. Chem. Rev. http://dx.doi.org/10.1016/j.ccr.2014.12.002

[16] C. Biot, Curr. Med. Chem. - Anti-Infective Agents 3 (2004) 135 - 147.

[17] P. Beagley, M.A.L. Blackie, K. Chibale, C. Clarkson, J.R. Moss, P.J. Smith, J. Chem. Soc., Dalton Trans. (2002) 4426 - 4433.

[18] C.S.K. Rajapakse, A.Martínez, B.Naoulou, A.A.Jarzecki, L.Suárez, C.

Deregnaucourt, V. Sinou, J. Schrével, E. Musi, G.Ambrosini, G.K. Schwartz, R.A. Sánchez-Delgado, Inorg. Chem. 48 (2009) 1122 - 1131.

[19] L. Glans, A. Ehnbom, C. de Kock, A. Martínez, J. Estrada, M. Haukka, R.A. Sánchez-Delgado, E. Nordlander, Dalton Trans. 41 (2012) 2764 - 2773.

[20] R.A. Sánchez-Delgado, A. Anzellotti, L. Suárez, Metal complexes as chemotherapeutic agents against tropical diseases: malaria, trypanosomiasis, and 
leishmaniasis in: H. Sigel, A. Sigel (Eds.), Metal ions in Biological Systems, 41, Marcel Dekker, New York, 2004, 379-419.

[21] L. Otero, M. Vieites, L. Boiani, A. Denicola, C. Rigol, L. Opazo, C. Olea-Azar, J. D. Maya, A. Morello, R. L. Krauth-Siegel, O.E. Piro, E. Castellano, M. González, D. Gambino, H. Cerecetto, J. Med. Chem. 49 (2006) 3322-3331.

[22] M. Vieites, L. Otero, D. Santos, D. Gajardo, J. Toloza, R. Figueroa, E. Norambuena, C. Olea-Azar, G. Aguirre, H. Cerecetto, M. González, A. Morello, J.D. Maya, B. Garat, D. Gambino, J. Inorg. Biochem. 102 (2008) 1033-1043.

[23] M. Vieites, L. Otero, D. Santos, C. Olea-Azar, E. Norambuena, G. Aguirre, H. Cerecetto, M. González, U. Kemmerling, A. Morello, J. D. Maya, D. Gambino, J. Inorg. Biochem. 103 (2009) 411-418.

[24] M. Vieites, P. Smircich, M. Pagano, L. Otero, F. Luane, H. Terenzi, M.J. Prieto, V. Moreno, B. Garat, D. Gambino, J. Inorg. Biochem. 105 (2011) 1704-1711.

[25] A. Merlino, L. Otero, D. Gambino, E.L. Coitiño, Eur. J. Med. Chem. 46 (2011) 2639-2651.

[26] L. Otero, J. D. Maya, A. Morello, C. Rigol, G. Barriga, J. Rodriguez, C. Folch, E. Norambuena, M. González, C. Olea-Azar, H. Cerecetto, D. Gambino, Med. Chem. 4 (2008) 11-17.

[27] L. Otero, C. Folch, G. Barriga, C. Rigol, L. Opazo, M. Vieites, D. Gambino, H.

Cerecetto, E. Norambuena, C. Olea-Azar, Spectrochim. Acta Part A 70 (2008) 519-523. [28] D. Gambino, L. Otero, Inorg. Chim. Acta 393 (2012) 103-114.

[29] M. Cipriani, J. Toloza, L. Bradford, E. Putzu, M. Vieites, E. Curbelo, A. I. Tomaz, B. Garat, J. Guerrero, J. S. Gancheff, J. D. Maya, C. Olea Azar, D. Gambino, L. Otero, Eur. J. Inorg. Chem. 27 (2014) 4677 - 4689. 
[30] M. Pagano, B. Demoro, J. Toloza, L. Boiani, M. González, H. Cerecetto, C. OleaAzar, E. Norambuena, D. Gambino, L. Otero, Eur. J. Med Chem 44 (2009) 4937 - 4943. [31] C. Sarniguet, J. Toloza, M. Cipriani, M. Lapier, M. Vieites, Y. Toledano-Magaña, J. C. García-Ramos, L. Ruiz-Azuara, V. Virtudes Moreno, J. D. Maya, C. Olea Azar, D. Gambino, L. Otero, Biol. Trace Elem. Res. 159 (2014) 379 - 392.

[32] B. Demoro, C. Sarniguet, R. Sánchez-Delgado, M. Rossi, F. Caruso, C. Olea-Azar, V. Moreno, A. Medeiros, M.A. Comini, L. Otero, D. Gambino, Dalton Trans. 41 (2012) $1534-1543$.

[33] B. Demoro, M. Rossi, F. Caruso, D. Liebowitz, C. Olea-Azar, U. Kemmerling, J. D. Maya, H. Guiset, V. Moreno, C. Pizzo, G. Mahler, L. Otero, D. Gambino, Biol. Trace Elem. Res. 153 (2013) 371 - 381.

[34] C. S. Allardyce, A. Dorcier, C. Scolaro, P. J. Dyson, Appl. Organomet. Chem. 19 (2005) 1-10.

[35] L. Ronconi, P.J. Sadler, Coord. Chem. Rev. 251 (2007) 1633 - 1648.

[36] C.G. Hartinger, P.J. Dyson, Chem. Soc. Rev. 38 (2009) 391 - 401.

[37] P.J. Dyson, G. Sava, Dalton Trans. (2006) 1929 - 1933.

[38] W. Han Ang, P.J. Dyson, Eur. J. Inorg. Chem. (2006) 4003 - 4018.

[39] J.J. Nogueira Silva, W.R. Pavanelli, F.R. Salazar Gutierrez, F. Chagas Alves Lima, A.B. Ferreira da Silva, J. Santana Silva, D.W. Franco, J. Med. Chem. 51 (2008) 4104 4114.

[40] A. Martínez, T. Carreon, E. Iniguez, A. Anzellotti, A. Sánchez, M. TYan, A.

Sattler, L. Herrera, R. A. Maldonado, R.A. Sánchez-Delgado, J. Med. Chem. 55 (2012) $3867-3877$.

[41] M. H. Garcia, T. S. Morais, P. Florindo, M. F. M. Piedade, V. Moreno, C. Ciudad, V. Noe, J. Inorg. Biochem.103 (2009) 354 - 361. 
[42] V. Moreno, J. Lorenzo, F. X. Aviles, M. H. Garcia, J.Ribeiro, T. S. Morais, P. Florindo, M. P. Robalo, Bioinorg. Chem. Applications (2010) doi:10.1155/2010/936834.

[43] V. Moreno, M. Font-Bardia, T. Calvet, J. Lorenzo, F. X. Avilés, M. H. Garcia, T.

S. Morais, A. Valente, M. P. Robalo, J. Inorg. Biochem. 105 (2011) 241 - 249.

[44] T. S. Morais, T. J. L. Silva, F. Marques, M. P. Robalo, F. Avecilla, P. J. Amorim Madeira, P. J.G. Mendes, I. Santos, M. H. Garcia, J. Inorg. Biochem. 114 (2012) 65 74.

[45] T.S. Morais, F. Santos, L. Côrte-Real, F. Marques, M. P. Robalo, P. J. A. Madeira, M. H. Garcia, J. Inorg. Biochem. 122 (2013) 8 - 17.

[46] G. Aguirre, H. Cerecetto, M. González, D. Gambino, L. Otero, C. Olea-Azar, Rigol, A. Denicola, Bioorg. Med. Chem. 12 (2004) 4885-4893.

[47] A. Bergamo, C. Gaiddon, J.H.M. Schellens, J.H. Beijnen, G. Sava, J. Inorg. Biochem. 106 (2012) 90 - 99.

[48] D.D. Perrin, W.L.F. Amarego, D.R. Perrin, Purification of Laboratory Chemicals, $2^{\text {nd }}$ Ed., Pergamon, New York, 1980, pp. 65 - 371.

[49] M. I. Bruce, N. J. Windsor, Aust. J. Chem. 30 (1977) 1601- 1604.

[50] W. J. Geary, Coord. Chem. Rev. 7 (1971) 81 - 122.

[51] S. Muelas-Serrano, J. J. Nogal-Ruiz, A. Gómez-Barrio, Parasitol. Res. 86 (2002) $999-1002$.

[52] M. Faundez, L. Pino, P. Letelier, C. Ortiz, R. López, C. Seguel, J. Ferreira, M. Pavani, A. Morello, J. D. Maya, Antimicrob. Agents Chemother 49 (2005)126-130. [53] S. Biebinger, L.E. Wirtz, P. Lorenz, C. Clayton, Mol. Biochem. Parasitol. 85 (1997) 99 - 102.

[54] H. Hirumi, K. Hirumi, J. Parasitol. 75 (1989) 985 - 989. 
[55] M. Fernández, L. Becco, I. Correia, J. Benítez, O. E. Piro, G. A. Echeverria, A. Medeiros, M. Comini, M. L. Lavaggi, M. González, H. Cerecetto, V. Moreno, J. Costa Pessoa, B. Garat, D. Gambino, J. Inorg. Biochem. 127 (2013) 150 - 160.

[56] C. Hansch, A. Leo, The hydrophobic parameter: measurement and calculation; In Exploring QSAR. Fundamentals and Applications in Chemistry and Biology, American Chemical Society Ed., Washington, 1995, pp 97 - 124.

[57] H. Cerecetto, R. Di Maio, M. González, M. Risso, P. Saenz, G. Seoane, A. Denicola, G. Peluffo, C. Quijano, C. Olea-Azar, J. Med. Chem. 42 (1999) 1941 - 1950. [58] C. Urquiola, M. Vieites, G. Aguirre, A. Marín, B. Solano, G. Arrambide, P. Noblía, M. L. Lavaggi, M.H. Torre, M. González, A. Monge, D. Gambino, H. Cerecetto, Bioorg. Med. Chem. 14 (2006) 5503 - 5509.

[59] J. K. Barton, J. M. Goldberg, Ch. V. Kumar, N. J. Turro, J. Am. Chem. Soc. 108 (1986) 2081 - 2088.

[60] J.R. Lakowicz, Principles of Fluorescence Spectroscopy, 3rd. ed.Springer Science, New York, 2006, Chapter 8.

[61] D. Gambino, L. Otero, M. Vieites, M. Boiani, M. González, E.J. Baran, H. Cerecetto, Spectrochim. Acta Part A Mol. Biomol. Spectrosc. 68 (2007) 341 - 348. [62] E. A. Nyawade, H. B. Friedrich, B. Omondi, Inorg. Chim. Acta 415 (2014) 44 - 51. [63] E.R. Brown, R.F. Large (1971) In: Weisberger A, Rositer BW (eds) Part IIA, Chapter 6. Interscience, New York.

[64] C. Rigol, C. Olea-Azar, F. Mendizabal, L. Otero, D. Gambino, M. Gonzalez, H. Cerecetto, Spectrochim. Acta A Mol. Biomol. Spectrosc. 61(2005) 2933 - 2938. [65] E.H. Kerns, L. Di, Drug-like properties: Concepts, structure design and methods from ADME to toxicity optimization. Academic Press, Amsterdam, 2008. [66] K. Makino, T. Hagiwara, A. Murakami, Radiat. Phys. Chem. 37 (1991) 657 - 665. 
[67] B. Aguilera-Venegas, C. Olea-Azar, V. Arán, J.D. Maya, U. Kemmerling, H.

Speisky, F. Mendizábal, Int. J. Electrochem. Sci. 7 (2012) 5837 - 5863.

[68] M.J. Waring, J. Mol. Biol. 13 (1965) 269 - 282.

[69] C. Tan, J. Liu, L. M. Chen, S. Shi, L. N. Ji, J. Inorg. Biochem. 102 (2008) 1644 1653.

[70] B. Wu, L. Gao, Z. Duan, K. Wang, J. Inorg. Biochem. 99 (2005) 1685-1691. 
Tables

Table 1. Selected electrochemical data for $\left[\mathrm{RuCp}\left(\mathrm{PPh}_{3}\right) \mathrm{L}\right]$ in $1 \mathrm{mM}$ DMSO solutions at a scan rate of $100 \mathrm{mV} / \mathrm{s}$.

\begin{tabular}{|c|c|c|c|c|c|}
\hline \multirow{2}{*}{ Compound } & $\operatorname{Ru}(\mathrm{II}) / \mathbf{R u}(\mathrm{III})$ & Couple I & \multicolumn{2}{|c|}{ Couple II (HL $\left.{ }^{c}\right)$} & \multirow{2}{*}{$\begin{array}{l}\text { Couple III } \\
{ }^{{ }^{b}} \mathbf{E}_{\mathrm{pc}}(\mathrm{V})\end{array}$} \\
\hline & ${ }^{\mathrm{a}} \mathbf{E}_{1 / 2}(\mathrm{~V})$ & ${ }^{b} \mathbf{E}_{\mathbf{p c}}(\mathbf{V})$ & ${ }^{\mathbf{b}} \mathbf{E}_{\mathrm{pa}}(\mathbf{V})$ & ${ }^{b} \mathbf{E}_{\mathrm{pc}}(\mathbf{V})$ & \\
\hline$\left[\mathrm{RuCp}\left(\mathrm{PPh}_{3}\right) \mathrm{L1}\right]$ & 0.40 & -0.63 & $-0.98(-1.00)$ & $-1.04(-1.09)$ & -1.95 \\
\hline$\left[\mathrm{RuCp}\left(\mathrm{PPh}_{3}\right) \mathrm{L2}\right]$ & 0.40 & -0.63 & $-0.98(-1.02)$ & $-1.06(-1.11)$ & -1.95 \\
\hline$\left[\mathrm{RuCp}\left(\mathrm{PPh}_{3}\right) \mathrm{L3}\right]$ & 0.45 & -0.51 & $-0.94(-0.99)$ & $-1.02(-1.07)$ & -1.82 \\
\hline
\end{tabular}

${ }^{\mathrm{a}}$ measured $v s . \mathrm{Ag} / \mathrm{AgCl} ;{ }^{\mathrm{b}}$ measured $v s . \mathrm{Ag} / \mathrm{Ag}^{+} ;{ }^{\mathrm{c}}$ from reference [29]

$\mathrm{E}_{\mathrm{pc}}=$ cathodic peak potential; $\mathrm{E}_{\mathrm{pa}}=$ anodic peak potential, $\mathrm{E}_{1 / 2}=\left(\mathrm{E}_{\mathrm{pa}}+\mathrm{E}_{\mathrm{pc}}\right) / 2$ 
Table 2. In vitro activity (measured as the $\mathrm{IC}_{50}$ value, the half inhibitory concentration) against T. cruzi, T. brucei brucei, cytotoxicity on murine macrophages J774 and EA.hy926 endothelial cells and selectivity index (SI) values of $\left[\mathrm{RuCp}\left(\mathrm{PPh}_{3}\right) \mathrm{L}\right]$ and of $\mathrm{HL}$ (included for comparison).

\begin{tabular}{|c|c|c|c|c|c|c|}
\hline Compound & $\begin{array}{c}\text { T. cruzi } \\
\text { IC }_{50} / \mu \mathrm{M}\end{array}$ & $\begin{array}{l}\text { T. brucei } \\
\mathrm{IC}_{50} / \mu \mathrm{M}\end{array}$ & $\begin{array}{l}\text { macrophages } \\
\qquad \mathrm{IC}_{50} / \mu \mathrm{M}\end{array}$ & $\begin{array}{l}\text { EA.hy926 } \\
\text { IC }_{50} / \mu \mathrm{M}\end{array}$ & SI (fold) & SI (fold) \\
\hline HL1 & $17.4 \pm 1.9^{\mathrm{c}}$ & $11.3^{\mathrm{e}}$ & $36.4 \pm 4.2^{\mathrm{c}}$ & $>100^{\mathrm{f}}$ & $2^{\mathrm{g}}\left(>6^{\mathrm{h}}\right)$ & $3^{i}\left(9^{j}\right)$ \\
\hline$\left[\mathrm{RuCp}\left(\mathrm{PPh}_{3}\right) \mathrm{L1}\right]$ & $4.14 \pm 0.21$ & $14.9 \pm 1.4$ & $>20^{\mathrm{d}}$ & $>20^{\mathrm{d}}$ & $>5^{\mathrm{a}}$ & $>1^{b}$ \\
\hline HL2 & $18.5 \pm 1.7^{\mathrm{c}}$ & $17.0^{\mathrm{e}}$ & $34.0 \pm 2.1^{\mathrm{c}}$ & $>100^{f}$ & $2^{\mathrm{g}}\left(>5^{\mathrm{h}}\right)$ & $2^{i}\left(>6^{j}\right)$ \\
\hline$\left[\mathrm{RuCp}\left(\mathrm{PPh}_{3}\right) \mathrm{L2}\right]$ & $0.41 \pm 0.02$ & $3.5 \pm 0.5$ & $>20^{\mathrm{d}}$ & $>20^{\mathrm{d}}$ & $>49^{\mathrm{a}}$ & $>6^{b}$ \\
\hline HL3 & $22.7 \pm 1.6^{\mathrm{c}}$ & $>100^{\mathrm{e}}$ & $>100^{c}$ & $>100^{f}$ & $>4^{\mathrm{a}}$ & - \\
\hline$\left[\mathrm{RuCp}\left(\mathrm{PPh}_{3}\right) \mathbf{L 3}\right]$ & $>20^{\mathrm{d}}$ & $10.7 \pm 0.2$ & $>20^{\mathrm{d}}$ & $>20^{\mathrm{d}}$ & - & $>2^{b}$ \\
\hline
\end{tabular}

${ }^{\mathrm{a}} \mathrm{SI}$ : $\mathrm{IC}_{50}$ macrophages or EA.hy926 / IC $\mathrm{IC}_{50} T$. cruzi. ${ }^{\mathrm{b}}{ }^{\mathrm{SI}}$ : $\mathrm{IC}_{50}$ macrophages or EA.hy926 / $\mathrm{IC}_{50} T$. brucei brucei. ${ }^{c}$ Data from ref. [33]. ${ }^{\mathrm{d}}$ not exactly determined due to low solubility of the compounds. Results are the mean value of three different independent experiments. ${ }^{\mathrm{e}}$ Data from ref. [32]. ${ }^{\mathrm{f}}$ Data from ref. [29]. ${ }^{\mathrm{g}}$ SI: $\mathrm{IC}_{50}$ macrophages / IC 50 T. cruzi. ${ }^{\mathrm{h}} \mathrm{SI}$ : $\mathrm{IC}_{50}$ EA.hy926 / IC ${ }_{50} T$. cruzi. ${ }^{\mathrm{i}} \mathrm{SI}$ : $\mathrm{IC}_{50}$ macrophages / $\mathrm{IC}_{50} T$. brucei brucei. ${ }^{\mathrm{j}} \mathrm{SI}: \mathrm{IC}_{50}$ EA.hy926 / $\mathrm{IC}_{50}$ T. brucei brucei. 
Table 3. $R_{\mathrm{M}}$ values of the $\left[\mathrm{RuCp}\left(\mathrm{PPh}_{3}\right) \mathrm{L}\right]$ complexes, the corresponding ligands and previously reported $\mathrm{Ru}(\mathrm{II})$ complexes with these ligands (mobile phase DMSO / physiological serum 60:40, v/v).

\begin{tabular}{|c|c|}
\hline Compound & $\boldsymbol{R}_{M}$ \\
\hline HL1 & $-0.5^{\mathrm{a}}$ \\
\hline$\left[\mathrm{RuCl}_{2}(\mathrm{HL} 1)_{2}\right]$ & $0.3^{\mathrm{a}}$ \\
\hline$\left[\mathrm{RuCl}_{2}(\mathrm{HL} 1)(\mathrm{HPTA})_{2}\right] \mathrm{Cl}_{2}$ & $0.7^{\mathrm{b}}$ \\
\hline$\left[\mathrm{RuCp}\left(\mathrm{PPh}_{3}\right) \mathrm{L} 1\right]$ & 0.6 \\
\hline HL2 & $-0.3^{\mathrm{a}}$ \\
\hline$\left[\mathrm{RuCl}_{2}(\mathrm{HL} 2)_{2}\right]$ & $0.5^{\mathrm{a}}$ \\
\hline$\left[\mathrm{RuCl}_{2}(\mathrm{HL} 2)(\mathrm{HPTA})_{2}\right] \mathrm{Cl}_{2}$ & $0.8^{\mathrm{b}}$ \\
\hline$\left[\mathrm{RuCp}\left(\mathrm{PPh}_{3}\right) \mathrm{L} 2\right]$ & 0.7 \\
\hline HL3 & $0.3^{\mathrm{a}}$ \\
\hline$\left[\mathrm{RuCl}_{2}(\mathrm{HL} 3)_{2}\right]$ & $1.0^{\mathrm{a}}$ \\
\hline$\left[\mathrm{RuCl}_{2}(\mathrm{HL} 3)(\mathrm{HPTA})_{2}\right] \mathrm{Cl}_{2}$ & $1.1^{\mathrm{b}}$ \\
\hline$\left[\mathrm{RuCp}\left(\mathrm{PPh}_{3}\right) \mathrm{L} 3\right]$ & 1.1 \\
\hline \multicolumn{2}{|c|}{$R_{\mathrm{M}}=\log _{10}\left[\left(1 / \mathrm{R}_{\mathrm{f}}\right)-1\right] ;{ }^{\mathrm{a}}$ data from ref. [31]; } \\
\hline
\end{tabular}


Table 4. Stern-Volmer constants of the $\left[\mathrm{RuCp}\left(\mathrm{PPh}_{3}\right) \mathrm{L}\right]$ systems for the competitive binding to DNA-EB in 2\% DMSO/TRIS HCl medium.

\begin{tabular}{|c|c|c|}
\hline Complex & $\boldsymbol{K}_{\mathbf{S V}}\left(\mathbf{M}^{-\mathbf{1}}\right)$ & $\log \boldsymbol{K}_{\mathbf{S V}}$ \\
\hline$\left[\mathbf{R u C p}\left(\mathbf{P P h}_{\mathbf{3}}\right) \mathbf{L 1}\right]$ & 3835 & 3.6 \\
\hline$\left[\mathbf{R u C p}\left(\mathbf{P P h}_{\mathbf{3}}\right) \mathbf{L 2}\right]$ & 5362 & 3.7 \\
\hline$\left[\mathbf{R u C p}\left(\mathbf{P P h}_{\mathbf{3}}\right) \mathbf{L 3}\right]$ & 16254 & 4.2 \\
\hline
\end{tabular}




\section{Figure legends}

Figure 1. Structure of the 5-nitrofuryl containing thiosemicarbazones HL selected as bioactive co-ligands and scheme of the synthesis and proposed structure of the $\left[\mathrm{RuCp}\left(\mathrm{PPh}_{3}\right) \mathrm{L}\right]$ compounds 1-3, where HL $=$ HL1 - HL3.

Figure 2. Cyclic voltammograms of $\left[\mathrm{RuCp}\left(\mathrm{PPh}_{3}\right) \mathrm{L}\right]$ in the anodic (left) and cathodic (right) directions at $100 \mathrm{mV} / \mathrm{s}$ scan rate in $1 \mathrm{mM}$ DMSO solutions. Potentials were measured vs. $\mathrm{Ag} / \mathrm{AgCl}$ (anodic scan) or $\mathrm{Ag} / \mathrm{Ag}^{+}$(cathodic scan).

Figure 3. Experimental (black) and simulated (red) ESR spectra obtained after $5 \mathrm{~min}$ incubation of [RuCp $\left.\left(\mathrm{PPh}_{3}\right) \mathrm{L} 2\right](1 \mathrm{mM})$ with $T$. cruzi epimastigotes (Dm28c strain, final protein concentration 4-8 mg/mL), NADPH (1 mM), and DMPO (100 mM). (“) characteristic signals of DMPO-nitrocompound spin adduct. (*) characteristic signals of DMPO-OH spin adduct. (\#) DMPO or DMPO-OH oxidation signals.

Figure 4. Relative fluorescence intensity $(\%)$ at $\lambda_{\mathrm{em}}=594 \mathrm{~nm}$ with increasing complex concentration obtained for the complexes. $\left(\mathrm{C}_{\mathrm{DNA}}=20 \mu \mathrm{M}, \mathrm{C}_{\mathrm{EB}}=10 \mu \mathrm{M}\right.$, samples prepared in $2 \% \mathrm{DMSO} / \mathrm{TRIS} \mathrm{HCl}$ medium, $30 \mathrm{~min}$ incubation at $37^{\circ} \mathrm{C}$ ). Squares: [RuCp$\left.\left(\mathrm{PPh}_{3}\right) \mathrm{L} 1\right]$, circles: [RuCp$\left.\left(\mathrm{PPh}_{3}\right) \mathrm{L} 2\right]$, triangles: [RuCp$\left.\left(\mathrm{PPh}_{3}\right) \mathrm{L} 3\right]$. 

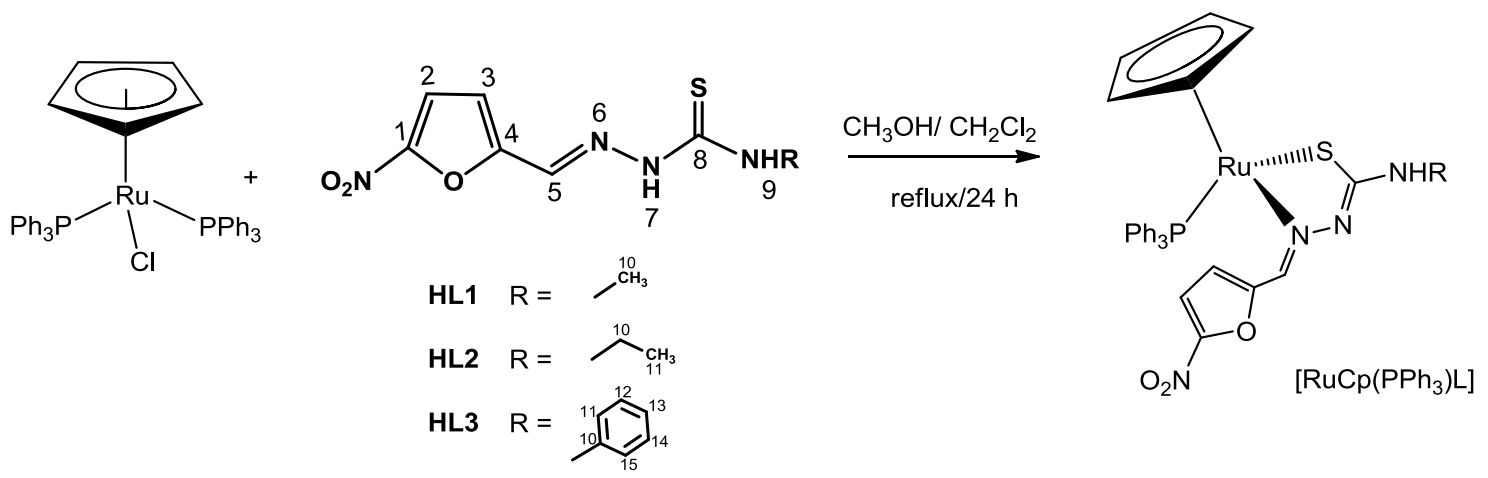

Figure 1 

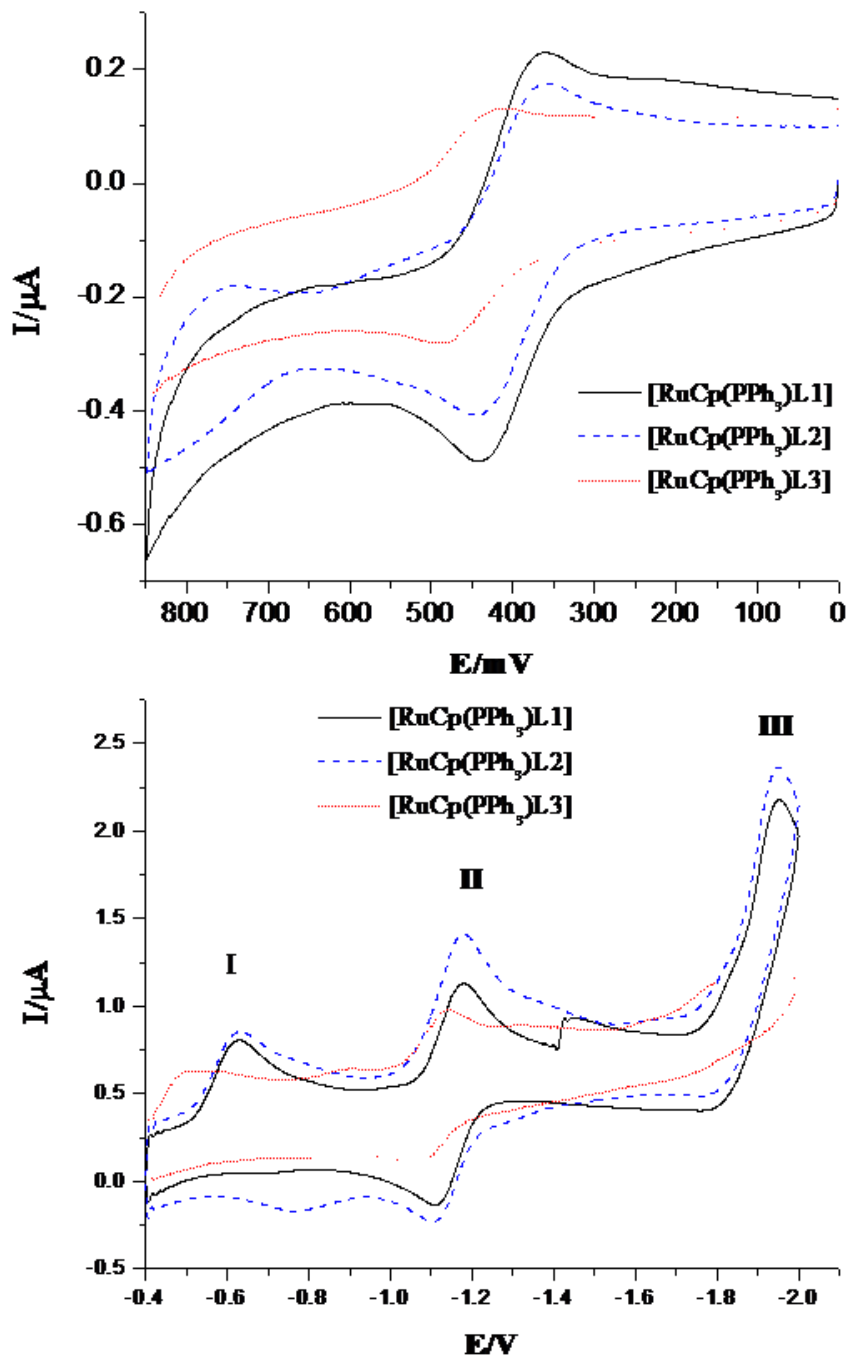

Figure 2 


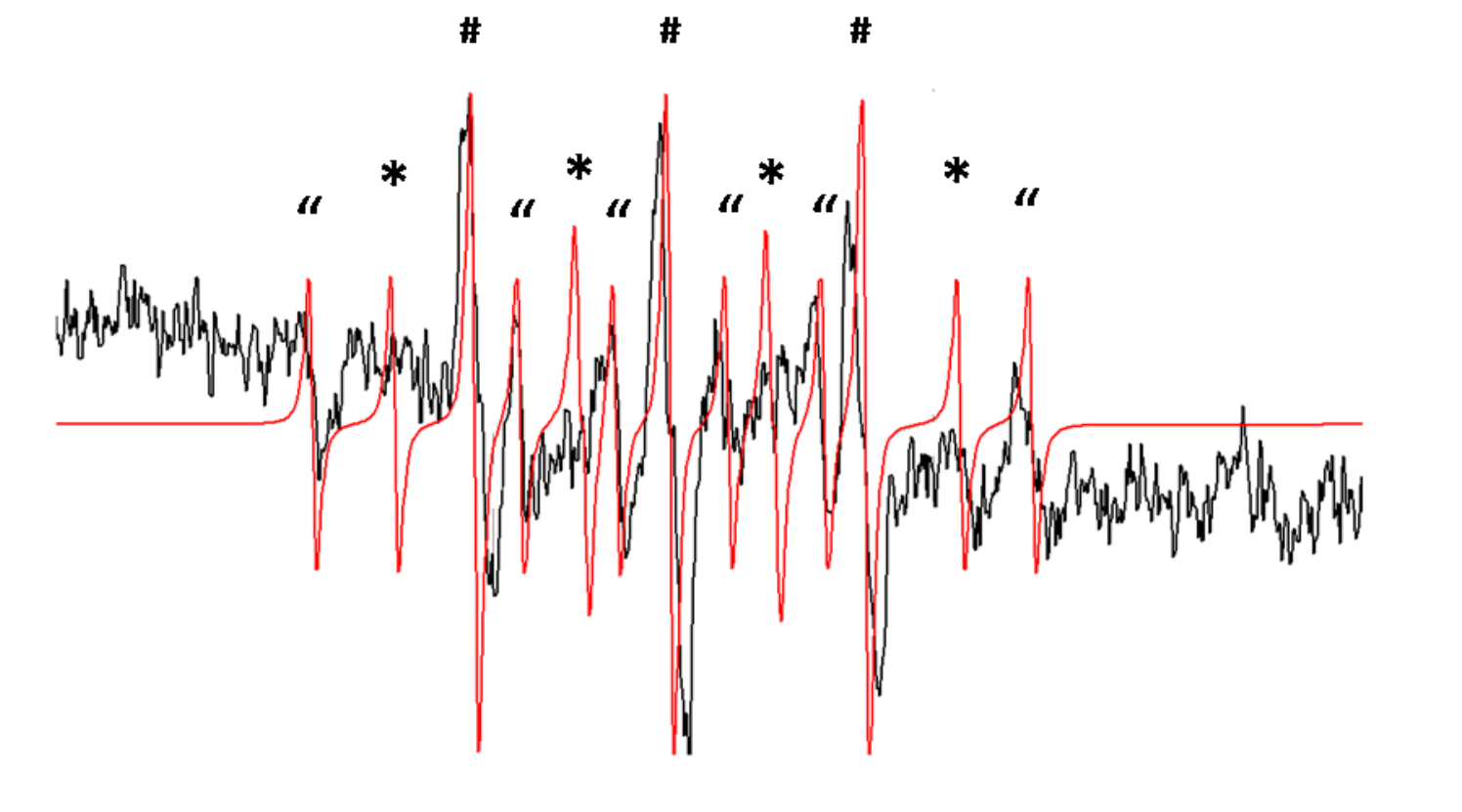

Figure 3 


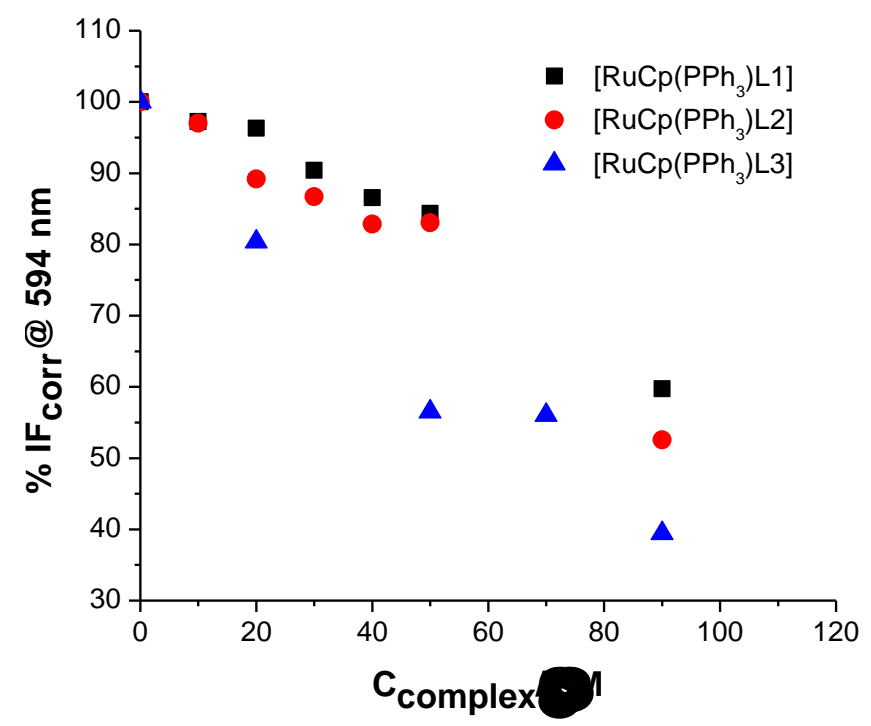

Figure 4 